Volume 1 Nomor 1, November 2020: h. 47 - 53

P-ISSN: 2722-4465, E-ISSN: 2746-8151

Creative Commons Attribution-NonCommercial 4.0 International

\title{
Karakteristik Hak Cipta Sebagai Objek Jaminan Fidusia
}

\section{Merry Tjoanda}

Fakultas Hukum Universitas Pattimura, Ambon, Indonesia.

E-mail: tjoanda.merry@gmail.com

\begin{tabular}{|c|c|}
\hline Dikirim: 30/08/2020 & Dipublikasi: 30/10/2020 \\
\hline Info Artikel & Abstract \\
\hline \multirow[t]{2}{*}{$\begin{array}{l}\text { Keywords: } \\
\text { Characteristics; Copyright; } \\
\text { Fiduciary Guarantee. }\end{array}$} & $\begin{array}{l}\text { A creator has the exclusive right to enjoy his own creation or to give } \\
\text { permission to others to use his creation. The purpose of this study is to } \\
\text { examine the characteristics of copyright that have the prospect of being } \\
\text { used as collateral for credit, because copyright has economic value and } \\
\text { can be transferred either entirely or partly because of inheritance, } \\
\text { grants, wills, written agreements or other justified reasons. by laws and } \\
\text { regulations. The method used is a type of normative legal research with } \\
\text { a statutory approach and a conceptual approach. The results show that } \\
\text { the characteristics of copyright as a fuduciary guarantee, which is an } \\
\text { intangible movable object, can be used as an object of fiduciary security, } \\
\text { even though the determination of the value or nominal value of } \\
\text { copyright has no standard provisions, but parties can ask for advice } \\
\text { from experts. }\end{array}$ \\
\hline & Abstrak \\
\hline $\begin{array}{l}\text { Kata Kunci: } \\
\text { Karakteristik; Hak Cipta, } \\
\text { Jaminan Fidusia. }\end{array}$ & $\begin{array}{l}\text { Seorang pencipta mempunyai hak eksklusif untuk menikmati } \\
\text { sendiri hasil ciptaannya atau memberikan ijin kepada orang lain } \\
\text { untuk menggunakan ciptaannya. Tujuan dari penelitian ini } \\
\text { untuk mengkaji karakteristik hak cipta yang mempunyai } \\
\text { prospek untuk dijadikan sebagai agunan kredit (collateral), } \\
\text { karena hak cipta memiliki nilai ekonomi dan dapat dialihkan } \\
\text { baik seluruhnya maupun sebagaian karena pewarisan, hibah, } \\
\text { wasiat, perjanjian tertulis atau sebab-sebab lain yang dibenarkan } \\
\text { oleh peraturan perundang-undangan. Metode yang digunakan } \\
\text { yaitu jenis penelitian hukum normatif dengan pendekatan } \\
\text { perundang-undangan, dan pendekatan konseptual. Hasil } \\
\text { penelitian menunjukan bahwa karakteristik hak cipta sebagai } \\
\text { jaminan fudusia yang merupakan benda bergerak tidak } \\
\text { berwujud, dapat dijadikan sebagai objek jaminan fidusia, } \\
\text { walaupun penentuan nilai atau nominal dari hak cipta belum } \\
\text { ada ketentuan yang baku akan tetapi para pihak dapat meminta } \\
\text { pertimbangan dari para ahli. }\end{array}$ \\
\hline
\end{tabular}

\section{Pendahuluan}

Hak cipta dipandang sebagai suatu unsur yang penting untuk melindungi hak-hak dari karya yang sifatnya estetis (Labetubun, 2011: 12), menunjukkan keaslian sebagai suatu 
ciptaan seseorang atas dasar kemampuan dan kreatifitasnya yang bersifat pribadi (Labetubun \& Fataruba, 2016: 9). Pasal 1 Undang-Undang Nomor 28 Tahun 2014 Tentang Hak Cipta mengemukanan bahwa Hak cipta adalah hak eksklusif pencipta yang timbul secara otomatis berdasarkan prinsip deklaratif setelah suatu ciptaan diwujudkan dalam bentuk nyata tanpa mengurangi pembatasan sesuai dengan ketentuan peraturan perundang-undangan. Menurut Sanusi, istilah Hak Cipta terdiri dari dua kata yang memiliki makna yang berbeda, yaitu Hak yang tidak terlepas dengan sebuah kewajiban, hak ini bersifat bebas dapat digunakan atau tidak digunakan, dan hak ini diberikan kepada pencipta. Sedangkan Cipta adalah sebuah perasaan, pikiran, pengalaman dan pengetahuan, kerja otak atau intelektualitas manusia itu sendiri dan sangat berhubungan dengan Hak Cipta (Bintang, 1998: 1). Penulis sendiri berpendapat bahwa hak cipta adalah hak yang timbul karena kreasi intelektual yang dihasilkan melalui pemikiran atau otak manusia.

Perkembangan yang semakin pesat dalam bidang ilmu pengetahuan, teknologi, seni dan sastra menimbulkan kebutuhan akan adanya peningkatan perlindungan dan jaminan kepastian hukum bagi pencipta, pemegang hak cipta, dan juga pemilik hak terkait (Labetubun, 2018: 147). Terdapat dua hak yang dimiliki oleh pencipta yaitu hak moral dan hak ekonomi, dimana Hak Moral adalah hak yang melekat secara abadi pada diri pencipta dan Hak Ekonomi, yang adalah hak pencipta untuk mandapatkan manfaat ekonomi atas ciptaannya. Undang-Undang Nomor 28 Tahun 2014 Tentang Hak Cipta adalah salah satu bukti kepedulian dan peran serta Pemerintah Indonesia dalam melindungi hak kekayaan intelektual di negara ini. Terlebih lagi jika melihat Pasal 16 Ayat (3) yang menyebutkan bahwa "Hak Cipta dapat dijadikan sebagai objek jaminan Fidusia."

Prinsip Hak Cipta sebagai objek Jaminan Fidusia dalam Undang-Undang Nomor 28 Tahun 2014 Tentang Hak Cipta tidak lepas dari teori hukum alam yang menghargai setiap hasil akal pikiran manusia (Ulinnuha, 2017: 85).

Hak ekonomi yang melekat pada hak cipta membawa konsekuensi menjadi dapat dialihkan atau beralihnya hak cipta tersebut kepada pihak lain (Sari, 2016: 300), sehingga bisa dikatakan sebagai "game-changer" karena membawa perubahan besar terhadap Hak Ekonomi Pencipta mengingat ketentuan ini tidak diatur oleh Undang-Undang Hak Cipta sebelumnya yaitu Undang-Undang Nomor 19 Tahun 2002 Tentang Hak Cipta.

Hak Cipta sebagai objek Jaminan Fidusia harus tetap mengacu pada ketentuan UndangUndang 42 tahun 1999 tentang Jaminan Fidusia (Pertiwi \& Sukirno, 2019: 924), Pasal 1 Undang-Undang Nomor 42 Tahun 1999 Tentang Jaminan Fidusia bahwa fidusia adalah pengalihan hak kepemilikan suatu benda atas dasar kepercayaan dengan ketentuan bahwa benda yang hak kepemilikannya dialihkan tersebut, tetap dalam penguasaan pemilik benda. Menurut Elisabeth Nurhaini Butarbutar, fidusia merupakan lembaga jaminan atas dasar kepercayaan, tanpa harus menyerahkan fisik suatu benda yang dijaminkan (Butarbutar, 2012: 75). Sebagai salah satu lembaga jaminan kebendaan di Indonesia, Jaminan Fidusia diartikan sebagai jaminan yang diberikan dalam bentuk fidusia yang ditujukan kepada benda bergerak baik berwujud maupun tidak berwujud dan benda bergerak khususnya bangunan yang tidak dapat dibebani hak tanggungan sebagaimana yang dimaksud dalam Undang-Undang Hak Tanggungan.

Istilah benda merupakan terjemahan dari kata zaak (Belanda) dan material (Inggris). Di dalam berbagai literatur dikenal tiga macam pengertian benda yaitu (Subekti, 2003: 60):

1) Sebagai barang yang dapat dilihat atau berwujud (pengertian sempit);

2) Sebagai kekayaan seseorang berupa hak dan penghasilan;

3) Sebagai objek hukum, lawannya subjek hukum 
Pengertian benda dalam arti luas bisa dilihat pada Pasal 499 KUH Perdata yang berbunyi "Kebendaan adalah tiap-tiap barang dan tiap-tiap hak yang dapat dikuasai oleh hak milik", dalam sistem hukum perdata Barat (BW) yang berlaku di Indonesia, pengertian zaak (benda) sebagai objek hukum tidak hanya meliputi "benda yang berwujud" yang ditangkap dengan pancaindra, akan tetapi juga "benda yang tidak berwujud" yakni hak-hak atas barang yang berwujud (Tutik, 2010: 143). Meski Pengertian zaak dalam KUH Perdata tidak hanya meliputi benda yang berwujud tetapi juga benda yang tidak berwujud yang oleh beberapa sarjana disebut juga zaak dalam arti bagian dari harta kekayaan. Namun demikian, sebagian besar dari pasal-pasal KUH Perdata mengatur mengenai benda dalam arti benda yang berwujud (Masjchoen, 2000: 108).

Benda sebagai objek hukum dapat dibedakan menjadi 2 macam yaitu (Salim HS, 2009: 96):

1) Benda yang berwujud;

2) Benda yang tidak dapat diraba.

Benda yang berwujud adalah benda yang dapat dilihat dan diraba dengan pancaindra seperti tanah, rumah, binatang dan lain-lain, sedangkan benda yang tidak dapat diraba merupakan hasil pikiran dari seseorang, seperti hak pengarang, hak octroi, hak-hak tagihan (piutang) dan sebagainya.

Pasal 16 Ayat 1 Undang-Undang Nomor 28 Tahun 2014 Tentang Hak Cipta menjelaskan bahwa Hak Cipta merupakan benda bergerak tidak berwujud, hal ini karena hak cipta termasuk benda imateriil. Hak yang melekat pada diri pencipta sebagai pemegang hak cipta adalah hak eksklusif. Hak ekslusif terdiri atas hak moral dan hak ekonomi. Karena hak ekonomi inilah, pencipta bisa mendapatkan manfaat ekonomi atau keuntungan dari ciptaannya tersebut, oleh karena itu, hak cipta termasuk benda yang menjadi objek dari jaminan fidusia.

\section{Metode Penelitian}

Penelitian ini adalah penelitian hukum (Marzuki, 2007: 56). Penelitian hukum dilakukan untuk mencari pemecahan atas isu hukum yang timbul. Oleh karena itulah, penelitian hukum merupakan suatu penelitian di dalam kerangka know-how di dalam hukum. Hasil yang dicapai adalah untuk memberikan preskripsi mengenai apa yang seyogianya atas isu yang diajukan (Marzuki, 2007: 83), dengan demikian maka jenis penelitian yang digunakan adalah penelitian Yuridis Normatif yang menggunakan sumber bahan hukum yang di peroleh melalui studi kepustakaan dan peraturan perundang-undangan (Marzuki, 2007: 93).

\section{Hasil dan Pembahasan}

Indonesia menganut prinsip deklaratif, artinya pencipta bisa langsung memperoleh hak cipta secara otomatis tanpa harus melalui suatu formalitas tertentu. Hak cipta lahir dengan sendirinya sejak suatu ciptaan dilahirkan dalam bentuk kesatuan yang nyata dan bukan karena pendaftaran. Oleh karena itu, mencatatkan hak cipta bukanlah kewajiban bagi seorang pencipta.

Pasal 6 UU Jaminan Fidusia mewajibkan adanya uraian tentang benda yang menjadi objek jaminan fidusia. Menurut Munir Fuady, uraian benda yang menjadi objek jaminan fidusia termasuk bukti kepemilikan (Fuady, 2013: 121), dengan demikian, untuk memberikan suatu kepastian hukum terhadap hak cipta yang dijadikan objek jaminan fidusia, maka perlu dilakukan pencatatan yang diajukan pada Menteri Hukum dan HAM 
melalui Direktorat Jenderal HAKI. Pendaftaran tersebut hanya sebagai bukti dan tidak menimbulkan hak yang baru karena hak tersebut sudah dimiliki pencipta semenjak ciptaan tersebut dibuat dalam bentuk yang nyata.

Pencatatan hak cipta dilakukan dengan mengajukan permohonan secara tertulis dengan menggunakan Bahasa Indonesia oleh pencipta, pemegang hak cipta, pemilik hak terkait atau kuasanya. Permohonan tersebut dibuat secara elektronik maupun non elektronik dan dengan menyertakan contoh ciptaan, melampirkan surat pernyataan kepemilikan hak cipta dan membayar sejumlah biaya sebagaimana diatur dalam Pasal 66 UU Hak Cipta.

Eksistensi perjanjian jaminan sangat bergantung pada perjanjian pokoknya. Perjanjian jaminan ditujukan untuk mengubah kedudukan kreditor-kreditor menjadi kreditor preferent (kreditor yang diutamakan) sehingga kreditor akan merasa aman dan memperoleh kepastian hukum terkait pelunasan pinjaman yang diberikan kepada debitor. Pasal 4 UU Jaminan Fidusia menyebutkan bahwa jaminan fidusia merupakan perjanjian ikutan dari suatu perjanjian pokok yang menimbulkan kewajiban bagi para pihak untuk memenuhi suatu prestasi. Kata "perjanjian ikutan" pada Pasal 4 UU Jaminan Fidusia menunjukan bahwa jaminan fidusia merupakan perjanjian yang bersifat accessoir. Sebagai perjanjian accessoir, maka perjanjian jaminan fidusia memiliki sifat (Widjaya \& Yani, 2001: 125):

1) Ketergantungan pada perjanjian pokok;

2) Keabsahannya semata-mata ditentukan oleh sah tidaknya perjanjian pokok;

3) Sebagai perjanjian bersyarat, maka hanya dapat dilaksanakan jika ketentuan yang diisyaratkan dalam perjanjian pokok telah atau tidak dipenuhi.

Berdasarkan Pasal 13 Ayat (2) UU Jaminan Fidusia, yang berhak mengajukan Permohonan Pendaftaran Jaminan Fidusia adalah penerima fidusia, kuasa atau wakilnya dengan melampirkan pernyataan pendaftaran jaminan fidusia, yang memuat (Widjaya \& Yani, 2001: 140):

1) Identitas Pihak Pemberi dan Pihak Penerima;

Identitas yang dimaksudkan dalam Pasal ini adalah nama lengkap, agama, tempat tinggal atau tempat kedudukan, tempat dan tanggal lahir, jenis kelamin, status perkawinan dan pekerjaan (Fuady, 2013: 121). Subjek dari jaminan fidusia adalah pihak pemberi fidusia dan pihak penerima fidusia. Pihak Pemberi fidusia adalah orang perseorangan atau korporasi pemilik benda yang menjadi yang menjadi objek jaminan fidusia. Sedangkan pihak penerima fidusia adalah Pemegang hak cipta atau pencipta yang berkedudukan sebagai debitor. Pasal 1 Ayat (6) UU Jaminan Fidusia mengatur bahwa pihak kreditor adalah orang perseorangan atau korporasi yang mempunyai piutang yang pembayarannya dijamin dengan jaminan fidusia.

2) Tanggal, Nomor Akta Jaminan Fidusia, nama, tempat kedudukan notaris yang membuat akta jaminan fidusia;

Akta notaris adalah akta otentik yang dibuat dan oleh atau dihadapan notaris menurut bentuk dan tata cara yang ditentukan oleh undang-undang. Pasal 5 ayat (1) UU Jaminan Fidusia mengatur mengenai pembebanan jaminan fidusia dibuat dengan akta notaris yang dibuat dengan menggunakan bahasa Indonesia dan merupakan akta jaminan fidusia.

3) Data perjanjian pokok;

Yang dimaksudkan dengan perjanjian pokok adalah mengenai macam perjanjian dan utang yang dijamin dengan dengan fidusia (Fuady, 2013: 121). Data yang memuat mengenai perjanjian pokok atau perjanjian utama yang dijamin dengan fidusia, misalnya utang yang sudah ada, utang yang sudah diperjanjikan dalam 
jumlah tertentu yang akan ada dikemudian hari, dan hutang yang ada pada saat eksekusi dapat ditentukan jumlahnya berdasarkan perjanjian pokok yang menimbulkan kewajiban.

4) Uraian mengenai benda yang menjadi objek jaminan fidusia;

Benda yang menjadi objek jaminan fidusia secara rinci terdapat dalam ketentuan Pasal 1 Ayat (4), Pasal 9, Pasal 10, dan Pasal 20 UU Jaminan Fidusia sebagai berikut (Fuady, 2013: 119):

a) Benda yang harus dapat dimiliki dan dialihkan secara hukum,

b) Benda berwujud,

c) Benda tidak berwujud termasuk di dalamnya berupa piutang,

d) Benda bergerak,

e) Benda tidak bergerak yang tidak dapat diikat dengan hak tanggungan,

f) Benda tidak bergerak yang tidak dapat diikat dengan hipotek,

g) Benda yang sudah ada, maupun terhadap benda yang akan diperoleh kemudian, dalam konteks benda yang akan diperoleh kemudian, tidak diperlukan suatu akta pembebanan fidusia tersendiri,

h) Satu satuan atau jenis berbeda,

i) Lebih dari satu jenis atau satu satuan benda,

j) Hasil dari benda yang telah menjadi objek fidusia,

k) Hasil klaim asuransi dari benda yang menjadi objek jaminan fidusia,

l) Benda persediaan,

m) Pesawat terbang dan helikopter yang telah terdaftar di Indonesia.

Hak cipta adalah benda bergerak tak berwujud, untuk itu dalam melakukan pendaftaran fidusia, perlu diuraikan lebih jauh mengenai hak cipta yang digunakan meliputi jenis maupun bukti kepemilikan hak cipta tersebut sebagai objek jaminan fidusia. Misalnya buku, maka uraiannya harus meliputi nama pengarang, judul buku, penerbit, tahun diterbitkan, banyaknya halaman.

5) Nilai penjaminan;

Yang dimaksudkan dengan nilai penjaminan adalah besar dari nilai hutang yang dimiliki oleh debitur. Syarat besarnya nilai penjaminan berkaitan dengan sifat hak jaminan sebagai hak mendahului atau preferen sebagaimana tercantum dalam Pasal 1 Angka (2) jo Pasal 27 UU Jaminan Fidusia.

6) Nilai benda yang menjadi objek jaminan fidusia;

Penetapan nilai atau nominal dari hak cipta yang akan dijadikan objek jaminan fidusia tergantung dari kesepakatan para pihak. Hal ini dikarenakan tidak semua hak cipta mempunyai nilai atau nominal yang sama. Sebagai contoh, buku yang laku dipasaran akan mempunyai nilai yang berbeda dengan buku yang kurang diminati. Apabila para pihak menemui kesulitan untuk menentukan nilai dari hak cipta, maka mereka bisa meminta pendapat para ahli yang memahami hak cipta tersebut.

Hak Cipta sebagai jaminan fidusia untuk sementara ini masih belum diminati oleh pelaku bisnis, hal ini dipengaruhi antara lain karena merasa hukumnya masih belum jelas dan nilai objeknya juga belum pernah diketahui nilai pasarannya seperti barang bergerak lainnya (Azmi et al., 2016: 104). Selain itu, penggunaan hak cipta sebagai objek jaminan fidusia bukan berarti tidak menimbulkan kendala khususnya bagi pihak pemberi fidusia dalam hal ini lembaga keuangan baik perbankan maupun lembaga keuangan non bank. Hal ini dikarenakan apabila debitur tidak memenuhi prestasinya (wanprestasi), nilai jaminan bisa saja tidak cukup untuk melunasi pinjaman. Hal ini dikarenakan nilai hak cipta cenderung tidak stabil dalam waktu yang lama. Sebagai contoh, buku yang populer dan laris 
di tahun ini, belum tentu akan tetap populer dan laris 10 tahun mendatang sehingga nilai dari aset tersebut otomatis akan berkurang. Dengan demikian,wajar jika tidak banyak lembaga keuangan di Indonesia yang memberikan fasilitas kredit fidusia dengan jaminan hak cipta.

\section{Kesimpulan}

Hak cipta sebagai benda bergerak tidak berwujud, dapat dijadikan sebagai objek jaminan fidusia. Hal ini dilakukan dengan mendaftarkan hak cipta demi mendapatkan status hukum bagi pencipta terhadap hasil ciptaannya sebelum digunakan sebagai jaminan pinjaman. Kesulitan untuk menentukan nilai atau nominal dari hak cipta yang akan digunakan sebagai objek jaminan fidusia bisa saja terjadi, tetapi hal ini bisa diatasi oleh para pihak dengan meminta pendapat para ahli.

\section{Daftar Referensi}

\section{Jurnal}

Azmi, M. Y., Hadi, H., \& Imanullah, M. N. (2016). Hak Cipta sebagai Jaminan Fidusia Ditinjau dari Undang-Undang Nomor 28 Tahun 2014 Tentang Hak Cipta dan UndangUndang Nomor 49 Tahun 1999 Tentang Jaminan Fidusia. Privat Law, IV(1), 97-106.

Labetubun, Muchtar A H. (2011). Perlindugan Hukum Desain Industri Di Dunia Maya ( Kajian Overlaping antara Hak Cipta Dengan Hak Desain Industri ). SASI, 17(4), 8-19.

Labetubun, Muchtar A H, \& Fataruba, S. (2016). Peralihan Hak Cipta Kepada Ahli Waris Menurut Hukum Perdata. SASI, 22(2), 1-11.

Labetubun, Muchtar Anshary Hamid. (2018). Aspek Hukum Hak Cipta Terhadap Buku Elektronik (E-Book) Sebagai Karya Kekayaan Intelektual. SASI, 24(2), 138-149.

Pertiwi, N. A., \& Sukirno. (2019). Pelaksanaan Hak Cipta Sebagai Objek Jaminan Fidusia. NOTARIUS, 12(2), 924-930. https:/ / doi.org/10.14710/nts.v12i2.29136

Sari, R. K. (2016). Hak Cipta sebagai Objek Jaminan Fidusia. Jurnal Lex Renaissance, 2(1), 293 307. https:// doi.org/10.20885/jlr.vol1.iss2.art10

Ulinnuha, L. (2017). Penggunaan Hak Cipta Sebagai Objek Jaminan Fidusia. Journal of Private and Commercial Law, 1(1), 85-110. https:/ / doi.org/10.15294/jpcl.v1i1.12357

Buku

Bintang, S. (1998). Hukum Hak Cipta, Dilengkapi dengan Susunan dalam Satu Naskah UU Hak Cipta (1982, 1987, 1997). Bandung: Citra Aditya Bakti.

Butarbutar, E. N. (2012). Hukum Harta Kekayaan. Bandung: Refika Aditama.

Fuady, M. (2013). Hukum Jaminan Utang. Jakarta: Erlangga.

Marzuki, P. M. (2007). Penelitian Hukum,. Jakarta: Kencana. https:// doi.org/340.072

Masjchoen, S. S. (2000). Hukum Perdata: Hukum Benda. Yogyakarta: Liberty.

Salim HS. (2009). Pengantar Hukum Perdata Tertulis (BW). Jakarta: Sinar Grafika.

Subekti. (2003). Pokok-Pokok Hukum Perdata. Jakarta: Intermasa.

Tutik, T. T. (2010). Hukum Perdata dalam Sistem Hukum Nasional. Jakarta: Prenada Media 


\section{Group.}

Widjaya, G., \& Yani, A. (2001). Jaminan Fidusia. Jakarta: Rajawali Pers. 